\title{
Urethral Injury Treatment Challenge. Comparison of Surgical Treatments for Acquired or latrogenic Urethral Stenosis and Predictive Values for Failure of Each Surgical Method
}

\author{
Yavuz Güler \\ Urology Clinics, Private Safa Hospital, Istanbul, Turkey
}

Corresponding author: Yavuz Güler, Urology Clinics, Private Safa Hospital, Istanbul, Turkey; E-mail: yavuzguler1976@gmail.com; Tel.: 05058120376

Received: 28 Apr 2020 Accepted: 30 July 2020 Published: 28 Feb 2021

Citation: Güler Y. Urethral injury treatment challenge. Comparison of surgical treatments for acquired or iatrogenic urethral stenosis and predictive values for failure of each surgical method. Folia Med (Plovdiv) 2021;63(1):42-50. doi: 10.3897/folmed.63.e53739.

\begin{abstract}
Introduction: Minimal invasive endo-urologic interventions and prostate surgeries performed through the urethral route are the most commonly used surgeries in the urology field at present. One of the unwanted complications weeks after some of these surgeries is urethral stenosis.
\end{abstract}

Aim: In this study, we aimed to review our treatment methods for patients with urethral stricture occurring after urologic interventions retrospectively to evaluate our success rates and data predicting recurrence and to determine the most feasible method.

Materials and methods: From 2008 to 2017, we evaluated retrospectively 234, 85, and 51 patients with urethral stenosis due to iatrogenic causes treated with direct visual internal urethrotomy (DVIU), anastomotic excision urethroplasty, and buccal graft urethroplasty, respectively. Postoperative Qmax above $15 \mathrm{~mL} / \mathrm{s}$ and $>17 \mathrm{CH}$ cystoscope easily passing the urethra was accepted as success for patients. Group variables were compared using ANOVA. Multivariate logistic regression analysis was performed to determine variables with predictive values. Predictive values significant in regression analysis $(p<0.005)$ were evaluated with ROC analysis.

Results: Patients were followed up for mean 48 (16-56) months, 48 (23-60) months, and 50 (32-65) months after DVIU, anastomotic and graft urethroplasty, respectively, and success was obtained for 75 (32.1\%), 71 (83.5\%) and 42 patients (82.4\%). Multivariate logistic regression analysis found age, DM, BMI and stenosis length were independent predictive factors for DVIU success, while stenosis length was the independent predictive factor for excision anastomosis and buccal graft urethroplasty success. Cut-off values were determined as 56.5 years of age, $30.2 \mathrm{~kg} / \mathrm{m}^{2}$ BMI and $1.85 \mathrm{~mm}$ stenosis length for DVIU patients, while $2.15 \mathrm{~mm}$ and 5.9 mm stenosis lengths, respectively, were determined for excision anastomosis and buccal graft urethroplasty with ROC analysis.

Conclusions: DVIU is a failed method for urethral stenosis in the long term. In contrast, resection / anastomosis and graft urethroplasty are very successful methods.

\section{Keywords}

anastomosis, buccal graft, stenosis, TUR-prostat, TUR-bladder carcinoma, urethra

Copyright by authors. This is an open access article distributed under the terms of the Creative Commons Attribution License (CC-BY 4.0), which permits unrestricted use, distribution, and reproduction in any medium, provided the original author and source are credited. 


\section{INTRODUCTION}

Iatrogenic stenosis is encountered as the most common cause of urethra stenosis in developed countries in the present day. ${ }^{1}$ It is known that the most common causes of iatrogenic urethral trauma are cystoscopy, ureterorenoscopy (URS), prostate, bladder and renal surgeries via the urethral route.

Iatrogenic urethral stenosis probably forms during surgery for primary disease due to mucosal injury and then completion of the healing process with dense fibrosis. This fibrotic tissue spreads to the corpus spongiosa tissue in the wall and around the injured urethra. Patients may attend with major complaints of reduced urinary flow rate a short time after primary surgery, feeling of not voiding urine, UTI (urinary tract infection), and urinary leakage. If not treated, it is a disease leading to postrenal kidney failure due to voiding problems in the upper urinary system, obstructive disease leading to renal tissue injury and lowered quality of life. $^{2}$

Diagnostic procedures firstly examine urinary flow rate with uroflowmetry, with retrograde urethrography and/or voiding cystourethrography taken to identify the localization and length of the stricture in patients with low maximum flow rate. For some patients, urethroscopy aids diagnosis. Treatment includes urethral dilatation, direct visual internal urethrotomy (DVIU) and urethroplasty (excision primary urethroplasty or EPA and substitution urethroplasty).

DVIU is a surgical method that is easy for both patient and clinician, can be performed on outpatients, is easily tolerated, and has limited complications. However, it has nearly no curative success especially in patients with long and complicated stenosis. In the literature, success of DVIU in a single session is reported to be from $0-50 \%$. As a result, it is necessary to use urethroplasty methods for definite curative success of complicated and long stenosis primarily and for recurrent stenosis after DVIU. EPA and substitution urethroplasty are open surgical methods for urethra stenosis. However, they are more difficult and complicated for surgeons and are surgical methods requiring expertise, their curative success is very good compared to DVIU. EPA can be used for shorter stenosis, while for longer stenosis it is necessary to use substitution urethroplasty.

To date, we estimate that DVIU has been used more than necessary due to surgeons not being masters of perineal surgery, patients are repeatedly operated in short intervals and patients are not sufficiently directed toward urethroplasty. In this study, we assessed our success with each of these 3 methods for primary aims by retrospectively investigating operation data for patients with iatrogenic urethral stenosis.

\section{MATERIALS AND METHODS}

From 2008 to 2017, patients with urethral stenosis occurring due to iatrogenic causes were retrospectively taken from the clinical records of a single clinic and single surgeon. As we could not access all records, the study did not include pediatric patients, patients with iatrogenic stenosis occurring due to urethral catheterization, hypospadias and radiation, and patients with panurethral and multiple stenoses. The study included patients without any missing data, $>16$ years of age, with urethral stenosis occurring after invasive endoscopic urethral entry surgeries and no treatment received including urethral dilatation. Of the 467 patients with records accessed, 370 met fully the inclusion criteria and were included in the study.

All patients with complaints about difficulty with lower urinary system voiding and urethral interventions in their history were dealt with under suspicion of iatrogenic urethral stenosis. Firstly, urine analysis and culture antibiograms, blood creatinine, urinary system ultrasonography (USG), and postmictional residual urine (PVR) measurements were performed. Uroflowmetry tests were performed to measure the urinary flow rate. Patients with urinary flow rate below $15 \mathrm{~mL} / \mathrm{s}$ and with suspected stricture at uroflowmetry had retrograde urethrography (RGP) and if necessary, voiding cystography (VCUG) performed to identify the localization and length of stenosis. Some patients had definite diagnosis of stenosis performed with urethroscopy. Patients with stenosis length below $1 \mathrm{~cm}$ were offered DVIU, patients with $2-3 \mathrm{~cm}$ stenosis were offered EPA, and patients with stenosis above $3 \mathrm{~cm}$ were offered buccal mucosal grafting (BMG) urethroplasty. Most of our patients who were offered urethroplasty shied away from it and decided on DVIU.

\section{DVIU operation technique}

All patients were operated under spinal anesthesia in dorsal lithotomy position. Urethroscopy was performed with a 20 F internal urethrotome (Karl Storz, 78532, Tutlingen, Germany), a guidewire (Cook Medical, Bloomington, USA) was sent from the stenosis lumen to the proximal and then a deep incision to mucosa and fibrotic tissue was made at 12 o'clock at the level of this wire and an $18 \mathrm{~F}$ Foley probe was inserted. All patients had the urethral catheter removed after 24 hours.

\section{EPA technique}

Patients were given spinal anesthesia and then laid on the table in the 30-degree Trendelenburg dorsal lithotomy position. The perineal region and surroundings were sterilized and incision was made on the penoscrotal or perineal midline, depending on the localization of the stenosis. In the perineal region, skin, subdermal colles fascia and bulbo-spongiosa muscle were separated on the midline (after subdermal layers without muscle in the peno-scrotal region) and the urethra was accessed. A ring retractor was used to better visualize the surgical field. To identify the localization of urethral stenosis, a bougie was used in the urethral catheter. Scar tissue was excised around the stenosis and 
above and below the stenosis, excision was performed to include some healthy urethral tissue. The two ends of the urethra had fish-mouth anastomosis performed on an $18 \mathrm{~F}$ silicon or Foley catheter. It was fixed with sutures passing through urethra periurethral tissue from the serosa. Then muscle and subdermal fascia were brought together and a $10 \mathrm{~F}$ silicon drain was inserted in the periurethral region. The drain was removed the next day with the urethral catheter removed at 10 days.

\section{BMG urethroplasty}

After spinal anesthesia, patients were placed on the table in 30-degree Trendelenburg dorsal lithotomy position. As with anastomotic end-to-end urethroplasty, midline incision was performed according to the localization of the stenosis. Stenosis was opened with dorsolateral urethrotomy. Oral buccal mucosa taken from inside the cheek was placed on the urethral plate and fixed with relaxant incisions made to the graft. The open ends of the urethrotomy were anastomosed to the graft edges above an $18 \mathrm{~F}$ silicon catheter. A $10 \mathrm{~F}$ silicon drain was inserted in the periurethral area and the field was closed as explained above. The drain was removed the next day with the urethral catheter removed 3 weeks later.

\section{Statistical analysis}

Statistics for the groups were performed using SPSS v. 22.09 (IBM Co, Armonk, NY, USA).Continuous variables were given as mean \pm standard deviation, while categoric variables were given as frequency and percentage (\%). Com- parison between groups of continuous variables used the ANOVA test, while the Kruskal Wallis test was used to test distribution in terms of group factors for categoric variables. Predictive factors affecting urethral stenosis success were assessed with multivariate logistic regression analysis and results are given as Odds ratio (ORs) and 95\% confidence intervals.

Variables found to be significant in multivariate models had receiver operating curve (ROC) analysis performed. Results were given as area under the curve (AUC) and 95\% confidence interval with sensitivity and specificity calculations interpreted for diagnostic performance. Variables found to be significant in terms of area under the curve had cut-off points calculated according to the Youden index.

\section{RESULTS}

In the DVIU, End-to-End and BMG groups, there were 234, 85 , and 51 patients, respectively. Mean and standard deviation for continuous demographic data of age, body mass index (BMI), American Society of Anesthesiology Score (ASA) and international prostate symptom score (IPSS) were $56.5 \pm 11.0$ years $(22-74, p=0.443), 26.3 \pm 3.5(19-34$, $p=0.224), 1.43 \pm 0.5(1-2, p=0.288)$, and $22.7 \pm 3.7(15-32$, $p=0.201$ ), respectively. There was no difference between the groups in terms of categoric demographic data like diabetes mellitus (DM), smoking history, coronary vascular disease (CVD) and etiologic causes of stenosis $(p>0.05)$. In the DVIU group, unlike the other two groups, there were patients with radical prostatectomy and adenomectomy in the etiology of stenosis $(p<0.001)$ (Table 1).

Table 1. Demographic classifications

\begin{tabular}{lllll}
\hline & DVIU & EPA & BMG & $p$ \\
\hline Patient, $\mathrm{n}$ & 234 & 85 & 51 & \\
Age, year & $56.96 \pm 10.90(22-74)$ & $57.70 \pm 10.8(31-69)$ & $54.8 \pm 11.2(27-65)$ & 0.443 \\
BMI, kg/m ${ }^{2}$ & $26.60 \pm 4.20(22-34)$ & $26.80 \pm 2.60(20-32)$ & $25.40 \pm 3.73(19-31)$ & 0.224 \\
ASA & $1.49 \pm 0.50(1-2)$ & $1.41 \pm 0.50(1-2)$ & $1.38 \pm 0.49(1-2)$ & 0.288 \\
DM, n (\%) & $51(21.8 \%)$ & $9(10.6 \%)$ & $5(9.8 \%)$ & 0.150 \\
Cigarette, n (\%) & $67(28.6 \%)$ & $25(29.4 \%)$ & $11(21.6 \%)$ & 0.644 \\
CVD, n (\%) & $28(12.0 \%)$ & $9(10.6 \%)$ & $6(11.8 \%)$ & 0.549 \\
IPSS & $23.4 \pm 4.1(16-32)$ & $21.7 \pm 3.2(15-26)$ & $23.0 \pm 3.7(16-32)$ & 0.201 \\
Etiology & & & & 0.183 \\
Cystoscopy/URS & $40(17.1 \%)$ & $13(11.8 \%)$ & $12(23.5 \%)$ & 0.123 \\
TUR-P & $113(48.3 \%)$ & $45(52.9 \%)$ & $25(49.0 \%)$ & 0.760 \\
TUR-B & $67(28.6 \%)$ & $27(31.8 \%)$ & $13(25.4 \%)$ & 0.345 \\
Radical prostatectomy & $7(3 \%)$ & - & - & N/A \\
Adenomectomy & $8(3.4 \%)$ & - & - & N/A \\
\hline
\end{tabular}

DVIU: direct vision urethroplasty; EPA: excision primary anastomosis; BMG: buccal mucosal grafting; ASA: The American Society of Anesthesiologists; BMI: body mass index; DM: diabetes mellitus; CVD: coronary vascular disease; IPSS: international prostate symptom score; TUR-P: transurethral prostatectomy; TUR-B: transurethral bladder tumorectomy; SD: standard deviation; Age, BMI, ASA, and IPSS are given as mean \pm SD (IQR). 
For surgical data, in DVIU, End-to-End and BMG, respectively, stenosis length was $2.48 \pm 2.17,1.64 \pm 0.96$, and $4.67 \pm 2.42 \mathrm{~cm}(p<0.001)$, success rates were 75 (32.1\%), 71 $(83.5 \%)$, and $42(82.4 \%)(p<0.001)$. The success rate in the DVIU group was significantly low compared to the other two groups $(p<0.001)$. According to Tukey posthoc analysis, there was no difference between end-to-end and BMG in terms of success rates $(p=0.755)$. There was no difference in success rates in the DVIU group according to localization of stenosis. Primary surgical success in the end-to-end and BMG groups was $90.2 \%$ and $93.5 \%$ with bulbar localization with $73.5 \%$ and $65 \%$ surgical success in the penile localization, respectively (Table 2 ).

For all three groups, the mean total follow-up duration after surgery was $49.6 \pm 8.0$ months. There was no significant difference between follow-up durations in the groups. In terms of postoperative complications, there was no difference in totals between the groups $(p=0.749)$, while in the end-to-end and BMG groups, wound site infections and temporary ejaculation disorders were observed, different to DVIU. Additionally, temporary urethro-cutaneous fistula was observed in 3 patients (5.8\%) from the BMG group. There were differences in terms of secondary or redo-tre- atments for patients with recurrent stenosis after primary treatment. In all three groups, DVIU was chosen most for secondary or redo operations. Additionally, whatever method patients received for primary treatment, most were observed to also choose the same method as secondary treatment. Postoperative IPSS scores were not different between the groups. We used the validated IPSS scores to observe objective surgical success. Total preoperative IPSS score of $22.8 \pm 3.8$ fell to $9.9 \pm 2.2$ in the assessment 1 month later (Table 2).

Multivariate logistic regression analysis found the independent predictive values for treatment success, given as OR, 95\% confidence interval (lower-upper) and $p$ values, were age (0.947-0.908-0.988-0.011), BMI (0.564-0.489$0.650-p<0.001)$, and length of stenosis (0.859- 0.742-0.9950.042) in the DVIU group; length of stenosis (0.098-0.0180.531- 0.007) in End-to-End group; and length of stenosis (0.176-0.043- 0.709-0.015) in BMG group (Table 3).

ROC analysis found cut-off, area under curve (AUC), sensitivity, specificity, 95\% confidence interval (CI) (lower-upper) and $p$ values for age: (56.5-0.772-0.817-0.672, $0.720-0.823, p<0.001)$, BMI $\left(27.3 \mathrm{~kg} / \mathrm{m}^{2}, 0.892,0.787\right.$, $0.847,0.859-0.926, p<0.001)$ and length of stenosis $(1.85$

Table 2. Surgical classifications

\begin{tabular}{|c|c|c|c|c|}
\hline & DVIU & EPA & BMG & $p$ \\
\hline Stricture location & & & & 0.143 \\
\hline Penile & $80(34.2 \%)$ & $34(40 \%)$ & $20(39.2 \%)$ & 0.176 \\
\hline Bulbar & $139(59.4 \%)$ & $51(60 \%)$ & $31(60.7 \%)$ & 0.954 \\
\hline Prostatic & $15(6.4 \%)$ & 0 & 0 & N/A \\
\hline Stricture length & $2.48 \pm 2.17(0.4-5)$ & $1.64 \pm 0.96(0.5-3.2)$ & $4.67 \pm 2.42(3-8)$ & $<0.001$ \\
\hline Success rate & $75(32.1 \%)$ & $71(83.5 \%)$ & $42(82.4 \%)$ & $<0.001^{\&}$ \\
\hline Penile & $27(33.8 \%)$ & $25(73.5 \%)$ & $13(65 \%)$ & $<0.001$ \\
\hline Bulbar & $42(30.2 \%)$ & $46(90.2 \%)$ & $29(93.5 \%)$ & $<0.001$ \\
\hline Prostatic & $5(33.3 \%)$ & - & - & - \\
\hline IPSS & $10.6 \pm 2.0(7-14)$ & $9.9 \pm 2.6(6-14)$ & $9.3 \pm 2.1(6-13)$ & 0.181 \\
\hline Follow-up & $47.4 \pm 5.7(24-56)$ & $49.1 \pm 7.8(33-60)$ & $52.2 \pm 8.6(32-65)$ & 0.120 \\
\hline Complications & $\begin{array}{l}\text { Clavien-Dindo } 1 \\
\text { Transient hematuria, } 23 \text { (9.8\%) } \\
\text { Dysuria, } 35(15.0 \%) \\
\text { Urge incontinence, } 24 \text { (10.3\%) } \\
\text { UTI, } 14(6.0 \%)\end{array}$ & $\begin{array}{l}\text { Clavien-Dindo } 1 \\
\text { Dysuria, } 11(12.9 \%) \\
\text { Urge incontinence, } 8(9.4 \%) \\
\text { UTI, } 6(7.0 \%) \\
\text { Wound infection, } 7(8.2 \%) \\
\text { Transient ejaculation disorders, } \\
7(8.2 \%)\end{array}$ & $\begin{array}{l}\text { Clavien-Dindo } 1 \\
\text { Urethrocutaneous fistula, } \\
3(5.8 \%) \\
\text { Dysuria, } 13(25.4 \%) \\
\text { Urge incontinence, } 7(13.7 \%) \\
\text { Wound infection, } 4(7.8 \%) \\
\text { Transient ejaculation disorders, } \\
5(9.8 \%)\end{array}$ & 0.749 \\
\hline Treatment of failure & & & & $<0.001$ \\
\hline Redo DVIU & $92(57.9 \%)$ & $8(57.2 \%)$ & $5(55.5 \%)$ & 0.876 \\
\hline RedoEndtoEnd & $42(26.4 \%)$ & $6(42.8 \%)$ & $1(11.1 \%)$ & $<0.001$ \\
\hline Redo BMG & $25(15.7 \%)$ & - & $3(33.3 \%)$ & $<0.001$ \\
\hline
\end{tabular}

SD: Standard deviation; UTI: urinary tract infection; IPSS: International Prostate Symptom Score; IQR: inter quartile range; Stricture length, follow-up, and IPSS are presented as mean \pm SD (IQR); other variables are given as percentage and numerical.

\&: EndtoEnd vs. BMG, 0.755 
Table 3. Independent predictive factors for success. Multıvariate regression analyses

\begin{tabular}{|c|c|c|c|c|c|c|c|c|c|}
\hline & \multicolumn{3}{|c|}{ DVIU } & \multicolumn{3}{|c|}{ EPA } & \multicolumn{3}{|c|}{ BMG } \\
\hline & & $95 \% \mathrm{CI}$ & & & 95\% CI & & & $95 \% \mathrm{CI}$ & \\
\hline & OR & Lower/Upper & $p$ & OR & Lower/Upper & $p$ & OR & Lower/Upper & $p$ \\
\hline Age & 0.947 & $0.908 / 0.988$ & 0.011 & 0.904 & $0.708 / 1.155$ & 0.421 & 1.088 & $0.878 / 1.350$ & 0.441 \\
\hline BMI & 0.564 & $0.489 / 0.650$ & $<0.001$ & 0.481 & $0.257 / 0.902$ & 0.083 & 0.832 & $0.530 / 1.307$ & 0.425 \\
\hline $\mathrm{DM}$ & 1.173 & $1.979 / 13.520$ & 0.453 & 2.968 & $0.250 / 35.282$ & 0.389 & 2.689 & $0.118 / 61.114$ & 0.535 \\
\hline Smoking & 0.932 & $0.467 / 1.859$ & 0.932 & 1.720 & $0.150 / 19.677$ & 0.663 & 0.439 & $0.017 / 11.047$ & 0.618 \\
\hline CVD & 2.167 & $0.734 / 6.386$ & 0.161 & 1.604 & $0.012 / 215.583$ & 0.850 & 0.520 & $0.016 / 16.716$ & 0.712 \\
\hline Etiology & 0.828 & $0.479 / 1.432$ & 0.499 & 0.057 & $0.002 / 1.612$ & 0.093 & 0.061 & $0.001 / 3.281$ & 0.169 \\
\hline Stricture length & 0.859 & $0.742 / 0.995$ & 0.042 & 0.098 & $0.018 / 0.531$ & 0.007 & 0.176 & $0.043 / 0.709$ & 0.015 \\
\hline Stricture location & 1.016 & $0.543 / 1.902$ & 0.961 & 1.910 & $0.135 / 26.932$ & 0.632 & 0.103 & $0.003 / 3.774$ & 0.216 \\
\hline
\end{tabular}

$p<0.005$, significant; OR: odds ratio; CI: confidence interval; CVD: cardio-vascular disease; BMI: body mass index

$\mathrm{mm}, 0.641,0.488,0.774,0.583-0.700, p<0.001)$ in Group 1

(Fig. 1) (Table 4); length of stenosis $(2.45 \mathrm{~mm}, 0.952,1.000$, 0.944, 0.904-0.988, $p<0.001$ ) in Group 2 (Fig. 2) (Table 4); and length of stenosis $(5.9 \mathrm{~cm}, 0.943,1.000,0.825,0.881$ $1.000, p<0.001$ ) in Group 3 (Fig. 3) (Table 4).

\section{DISCUSSION}

Currently, symptomatic urethral stenosis is treated with urethral dilatation, DVIU, EPA and substitution urethroplasty surgeries. Historically, though urologists know that urethral dilatation and DVIU treatments are far from permanent success for urethral stenosis, it is a reality that curative treatments like excision anastomosis and substitution urethroplasty are performed less frequently. But in recent years, urologists appear to have caught the trend of open urethral surgeries from endoscopy for urethral stenosis treatments after curiosity about perineal surgery. Xu et al. ${ }^{2}$, in a multicentric study including 4764 patients, applied DVIU, EPA and substitution urethroplasty at rates of $36.5 \%, 31.4 \%$

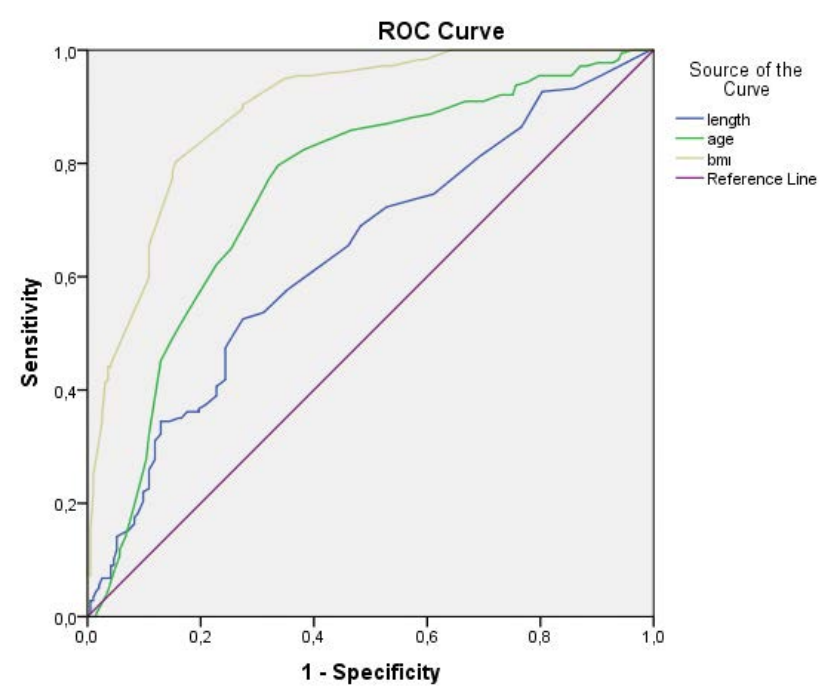

Figure 1. Area under curve of predictive values in DVIU failure are shown in the ROC analysis curve.

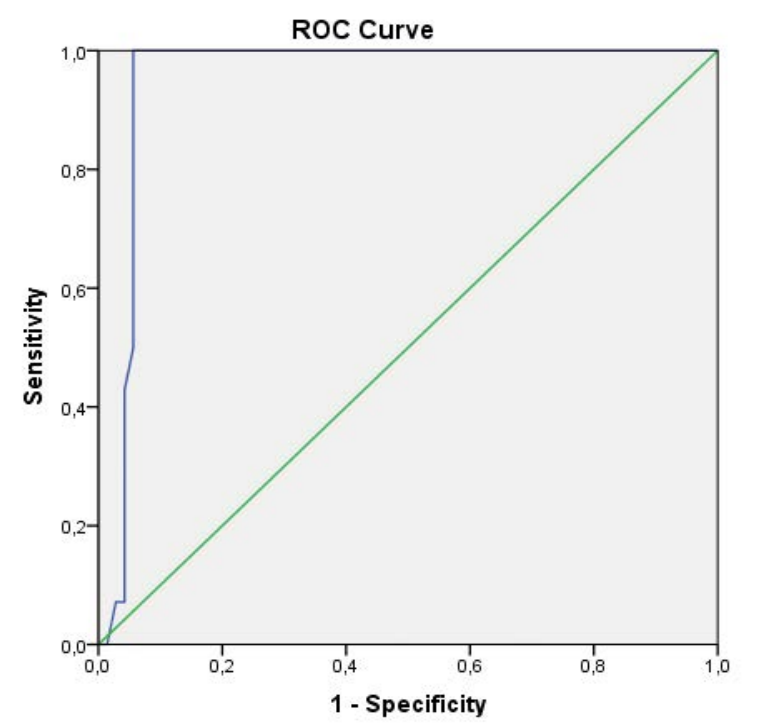

Figure 2. The area under the curve of the length of the stenosispredictive value of END-END anastomosis failure, is shown on the ROC analysis curve.

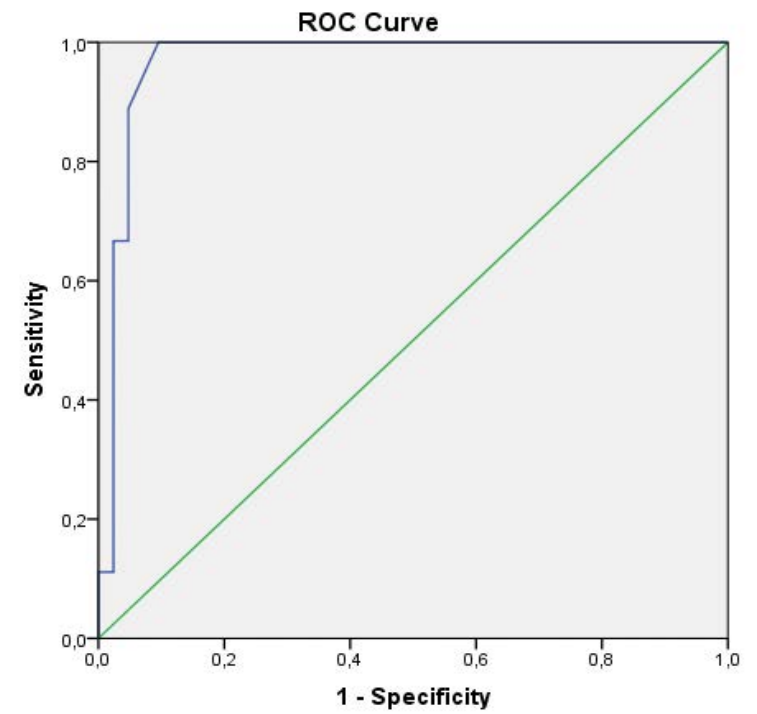

Figure 3. The area under curve of the length of stenosis, which is the predictive value of BMG urethroplasty failure, is shown in the ROC analysis curve. 
Table 4. Results from the receiver operating characteristics analysis

\begin{tabular}{lllllll}
\hline & Cut-off & AUC & Sensitivity & Specificity & $\begin{array}{l}\text { 95\% CI } \\
\text { Lower / Upper }\end{array}$ & $\boldsymbol{p}$ \\
\hline $\begin{array}{l}\text { DVIU } \\
\quad \text { Age }\end{array}$ & 56.5 & 0.772 & 0.817 & 0.672 & $0.720 / 0.823$ & $<0.001$ \\
$\quad$ BMI & 30.2 & 0.892 & 0.787 & 0.847 & $0.859 / 0.926$ & $<0.001$ \\
$\quad$ Stricture length & 1.85 & 0.641 & 0.488 & 0.774 & $0.583 / 0.700$ & $<0.001$ \\
EPA & & & & & $0.904 / 0.999$ & $<0.001$ \\
$\quad$ Stricture length & 2.15 & 0.952 & 1.000 & 0.944 & & $<0.001$ \\
$\quad \begin{array}{l}\text { BMG } \\
\quad \text { Stricture length }\end{array}$ & 5.9 & 0.943 & 1.000 & 0.825 & $0.881 / 1.000$ & \\
\hline
\end{tabular}

ROC: receiver operating characteristics; BMI: body mass index

and $21.8 \%$ with endoscopic surgeries regressing by $18 \%$ in the last 3 years and anastomotic and substitution urethroplasty increasing by $8 \%$ and $6 \%$, respectively.

DVIU is currently the most commonly chosen urethral stenosis surgery in the world. The main reasons for choosing it are ease of application, high patient tolerance and being an outpatient surgery. However, while the short-term success of DVIU is $50-85 \%$, long-term surgical success falls to $6-28 \%$,as with the success rate obtained in our study. 3,4 Furthermore, as the number of sessions increases, the longterm success rate reduces further and there may be requirements for repeated surgery or dilatation or urethroplasty. ${ }^{5}$ Most studies have reported negative predictive factors for DVIU success as long penile localization, recurrent and periurethral spongiofibrosis stenosis. ${ }^{4}$ The effect of factors like etiology of stenosis, previous open urethroplasty, perioperative UTI, advanced age, smoking, DM, CVD, and BMI on success is controversial., 6

The length of urethral stenosis is a factor affecting success after DVIU. ${ }^{6}$ Redon-Galvez et al. ${ }^{8}$ identified $37 \%$ relapse and length of stenosis $>1 \mathrm{~cm}$ as the only independent risk factors for DVIU failure. Pansadoro and Emiliozzi ${ }^{9}$ reported recurrence in $71 \%$ of strictures with length $>10 \mathrm{~mm}$ after first urethrotomy, whereas $18 \%$ of strictures $<10 \mathrm{~mm}$ recurred after first urethrotomy. Albers et al. ${ }^{10}$ reported recurrence in $51 \%$ of strictures with length $>10 \mathrm{~mm}$ after first urethrotomy, whereas $28 \%$ of strictures $<10 \mathrm{~mm}$ recurred after first urethrotomy. In our study, we identified stenosis length of $1.85 \mathrm{~cm}$ as an independent predictive variable for DVIU success. This and similar studies will contribute to the literature on this topic; however, it is a reality that there is a need for multicentric prospective randomized studies to determine appropriate length of stenosis.

For long and recurrent stricture, the main factor lowering success of DVIU is periurethral spongiofibrosis tissue. While retrograde (RGP) and/or antegrade urethrography (VCUG) can determine the localization and length of stenosis, it is not possible to understand the presence or width of spongiofibrosis outside the urethra. Though an idea may be gained with the aid of magnetic resonance imaging (MRI) and USG, it is difficult to fully determine the fibrosis tissue. It is known that this periurethral fibrosis tissue thickens with long strictures and repeated surgeries.

In DVIU patients, age and BMI were the other independent predictive variables. Patients with advanced age and high BMI are predicted to have more difficult urethral mucosal amelioration after surgery and more recurrence of stenosis. Harraz et al. ${ }^{7}$ monitored $<2 \mathrm{~cm}$ bulbar urethral stenosis for mean 29 (3-132) months and obtained 58.1\% success. They reported advanced age, obesity and idiopathic stenosis were independent predictive factors for failure of DVIU surgery. However, contrary to this, Kizilay et al. ${ }^{11}$ identified urethral stenosis recurred earlier in patients aged $<60$ years, and after second and advanced sessions of DVIU surgery. In our study, the cut-off value of 56.5 years was identified as an independent predictive variable for operation success and this leads to debate about whether the age factor is a true predictive factor for DVIU success. Some studies have reported that high BMI lowers operation success. $^{7,12}$ In our study, we identified $30.3 \mathrm{~kg} / \mathrm{m}^{2}$ BMI value as the cut-off. We believe prospective studies will resolve whether age and BMI variables are significant factors or not and the cut-off limit debates.

For patients with recurrent stenosis after DVIU, the topic of continuation with repeated DVIU and urethral dilatations or transfer to urethroplasty is controversial. The Society of International Urology (SIU) recommends urethral dilatation after stenosis recurring less than 6 months after DVIU and redo-DIVU, while the American Society of Urology Association (AUA) recommends transition to open urethroplasty. ${ }^{13}$ Of course, while making this decision, it is necessary to examine the patient's quality of life, expectations, compliance and whether they can cope with more serious surgery and anesthesia. For patients with recurrent stenosis after DVIU, urethroplasty is reported to be a more successful surgical choice. For short stenosis fibrosectomy + stenosectomy + excision anastomosis (EPA) and for longer stenosis buccal mucosa graft urethroplasty or penile skin flap urethroplasty may be applied.

EPA surgery is reported to be very successful (85-90\%) when appropriate patient selection is performed. It is especially recommended for patients with $1-2 \mathrm{~cm}$, redo-urethr- 
oplasty and urethral stenosis with high spongiofibrosis due to traumatic reasons. Just as with primary excision and excision anastomosis according to the width of fibrotic tissue, if fibrosis is excessive and primary approach after excision will cause problems, augmented anastomotic and nontransecting anastomotic urethroplasty forms may be applied..$^{14}$

In our study, as independent predictive factor for success of EPA surgery, we identified the urethral stenosis length cut-off value was $2.15 \mathrm{~cm}$. We did not encounter any studies in the literature reporting stenosis length cutoff values; however, we know stenosis $<2 \mathrm{~cm}$ can be very successfully treated with EPA. Carranci et al. ${ }^{15}$ obtained $80 \%$ success in mean 5.4-year follow-up for bulbomembranous urethra stenosis, and reported most patients with failure were healed with repeated single DVIU. Ortiz et al. ${ }^{16}$ presented 45 -month outcomes for patients with bulbar urethral stenosis of 1-2 cm length and reported $92 \%$ success in a single session. Suh et al. ${ }^{17}$ achieved $87.5 \%$ success in bulbar urethra stenosis patients followed for mean 42.6 (8-96) months) and reported failure in patients with nontraumatic etiology. Saez-Barranguero et al. ${ }^{18}$ evaluated 105 cases with $91.6 \%$ having $1-2 \mathrm{~cm}$ stenosis and obtained $95.3 \%$ success with most having repeated EPA for recurrent stenosis. Shakir et al. ${ }^{19}$ obtained 93\% success for 43-month follow-up of 1-1.4 cm penile urethra stenosis and reported the surgery did not cause penile curvature and ED.

Our surgical success is within the $80-95 \%$ interval reported for EPA in the literature. Full excision of periurethral fibrosis and stenotic tissue in the urethra and then a relaxed anastomosis are the most important factors increasing success of this surgery. As a result, for patients selected for this surgery, short stricture is the most important element.

Buccal mucosal graft and/or facio-cutaneous flap urethroplasty is a surgical method independent of the length of the stenosis. These methods are chosen for patients with relatively longer stricture compared to anastomosis surgery. Currently substitution/augmentation urethroplasty is performed with grafts from a variety of tissues and by taking flaps from neighbouring tissues like penis and scrotum. However, at the present point, buccal mucosa graft transfer is reported to be the most successful method. Buccal mucosa may be transferred to the urethra as dorsal onlay, ventral onlay, Asopa dorsal inlay and double-face. Since described by Barbagli, dorsal onlay is the most commonly performed and most successful method for buccal mucosa transfer and remains popular in the present day. ${ }^{20}$

Virasoro et al. ${ }^{14}$ obtained $96.9 \%$ success rates after 33.13 months (12.7-52.77) follow-up for urethral stenosis patients with mean length of 3.95 (3-7) cm with $80 \%$ previously undergoing DVIU surgery and most due to idiopathic causes. Kulkarni et al. ${ }^{21}$ used 1 session, 1 side dissection dorsal onlay mucosal graft for mean length $14 \mathrm{~cm}$ panurethral stenosis and 59-month follow-up and obtained $83.7 \%$ success with primary urethroplasty and $61.5 \%$ success for cases with secondary urethroplasty. Meneghini et al. ${ }^{22}$ reported $80 \%$ success with mean 13 -month follow-up using ventral onlay for bulbar urethral stenosis of $2.5-5 \mathrm{~cm}$ (mean $3.6 \mathrm{~cm}$ ). Pansadoro et al. ${ }^{23}$ reported $97 \%$ success while presenting the buccal graft outcomes for bulbar urethral stenosis is a larger series. Mellon et al. ${ }^{24}$ followed patients with ventral onlay grafting with previous mean 2.83 (1-9) sessions of surgery for 39.3 months (6.6-127.3). Mean stenosis length was $3.14 \mathrm{~cm}$ (1-8) with $20.6 \%$ of patients requiring repeated operation. Horiguchi et al. ${ }^{25}$ used ventral and dorsal onlay graft insertion for mean graft size 2.5-12 cm (mean $4.6 \mathrm{~cm}$ ) with 14-month follow-up and reported oral mucosa grafting was a very successful method with penoscrotal fistula rarely developing and not even requiring treatment. In our study, our final success rate of $82.4 \%$ is parallel with the mean results from the literature.

Penile localization, length of stenosis, BMI, age, smoking, cardiovascular diseases, and surgeon experience are proposed to be the predictive factors effective on success of this surgery. In our study, multivariate regression analysis identified the only independent predictive factor affecting success of graft urethroplasty was stenosis length with 5.9 $\mathrm{cm}$ cut-off value. Rosenbaum et al. ${ }^{26}$ reported that urethroplasty had higher failure for penile localization, stenosis of $>4 \mathrm{~cm}$, primary endoscopic treatment and urethral stenosis caused by radiation in a review study. Kinnaird et al. ${ }^{27}$ reported smoking, previous urethroplasty, stricture localization, age above 50 years and stenosis larger than 5 $\mathrm{cm}$ had more recurrence after 52-month mean follow-up period. They reported increased risk of recurrence with lichen sclerosis, infectious and iatrogenic etiologies. They reported $75 \%$ of recurrence occurred in the first 6 months, and obtained $91 \%$ surgical success. For our recurrent stenosis cases, $75 \%$ occurred in the first 3 months with all recurrence observed in the first 6 months.

The greatest limitation of our study is that it is retrospective. Another handicap is the low number of EPA and buccal graft substitution surgeries. However, there are still no standardized guides related to urethral stenosis surgery, sufficient prospective studies and meta-analyses. Along with similar studies, we believe our study will act as a guide to determine suitable surgical methods for urethral stenosis patients.

\section{CONCLUSIONS}

For primary treatment, single-session EPA and BMG urethroplasty are superior to DVIU according to long-term success rates. The results of this retrospective study suggest that the primary repair of iatrogenic urethral lesions are better treated by EPA and BMG urethroplasty when compared with DVIU and what the extent of stenosis appears to be a determining factor for success. 


\section{REFERENCES}

1. Stein DMS, Thum DJ, Barbagli G, et al. A geographic analysis of male urethral stricture aetiology and location. BJU Int 2013; 112 (6):830-4.

2. Xu YM, Song LJ, Wang KJ, et al. Changing trends in the causes and management of male urethral stricture disease in China: an observational descriptive study from 13 centres. BJU Int 2015; 116(6):938-44.

3. Isono M, Horiguchi A, Tasaki S, et al. The efficacy of direct vision internal urethrotomy for male urethral stricture. Nihon Hinyokika Gakkai Zasshi 2012; 103(6):691-6.

4. Dubey D. The current role of direct vision internal urethrotomy and self-catheterization for anterior urethral strictures. Indian J Urol 2011; 27(3):392-6.

5. Wright JL, Wessells $\mathrm{H}$, Nathens AB, et al. What is the most cost-effective treatment for 1 to 2 -cm bulbar urethral strictures: societal approach using decision analysis. Urology 2006; 67(5):889-93.

6. Pal DK, Kumar S, Ghosh B. Direct visual internal urethrotomy: is it a durable treatment option? Urol Ann 2017; 9(1):18-22.

7. Harraz AM, El-Assmy A, Mahmoud O, et al. Is there a way to predict failure after direct vision internal urethrotomy for single and short bulbar urethral strictures? Arab J Urol 2015; 13(4):277-81.

8. Gálvez LR, Escudero RM, Ardura MA, et al. Predictors of urethral stricture recurrence after endoscopic urethrotomy. Actas Urol Esp 2016; 40(8):529-33.

9. Pansadoro V, Emiliozzi P. Internal urethrotomy in the management of anterior urethral strictures: Long-term follow-up. J Urol 1996; 156:73-5.

10. Albers P, Fichtner J, Brühl P, et al. Long-term results of internal urethrotomy. J Urol 1996; 156:1611-4.

11. Kizilay F, Şimşir A, Özyurt C. Analysis of recurrent urethral strictures due to iatrogenic urethral trauma. Turk J Med Sci 2017; 47(5):1543-8.

12. Privratsky JR, Almassi N, Guralnick ML. Outcomes of grafted bulbar urethroplasty in men with class II or III obesity. Urology 2011; 78(6):1420-3.

13. Bayne DB, Gaither TW, Awad MA, et al. Guidelines of guidelines: a review of urethral stricture evaluation, management, and follow-up. Transl Androl Uro 2017; 6(2):288-94.

14. Virasoro R, Storme OA, Capiel L. Buccal mucosa graft augmented anastomotic urethroplasty for the treatment of bulbar urethral strictures. Arch Esp Urol 2015; 68(10):730-7.

15. Carrancio LM, Pérez SG, Checci CC, et al. Stenosis of the membranous bulbar urethra: our experience in termino-terminal urethroplasty. Actas Urol Esp 1998; 22(4):350-3; discussion 354.

16. Ortíz MAG, Prados FJV, Buñuel MT, et al. Long-term results of endto-end urethroplasty. Actas Urol Esp 2005; 29(5):499-505.

17. Suh JG, Choi WS, Paick JS, et al. Surgical outcome of excision and end-to-end anastomosis for bulbar urethral stricture. Korean J Urol 2013; 54(7):442-7.

18. Barranquero FS, Imbroda BH, Gálvez Ay, et al. Anastomotic urethroplasty in bulbar urethral stricture. 13 years experience in a department of urology. Arch Esp Urol 2016; 69(1):24-31.

19. Shakir NA, Fuchs JS, Haney N, et al. Excision and primary anastomosis reconstruction for traumatic strictures of the pendulous urethra. Urology 2019; 125:234-8.

20. Barbagli G, Selli C, CelloVD, et al. A one-stage dorsal free-graft urethroplasty for bulbar urethral strictures. Br J Urol 1996; 78(6):929-32.

21. Kulkarni S, Barbagli G, Sansalone S, et al. One-sided anterior urethroplasty: a new dorsal onlay graft technique. BJU Int 2009; 104(8):1150-5.

22. Meneghini A, Cacciola A, Cavarretta L, et al. Bulbar urethral stricture repair with buccal mucosa graft urethroplasty. Eur Urol 2001; 39(3):264-7.

23. Pansadoro V, Emiliozzi P, Gaffi M, et al. Buccal mucosa urethroplasty for the treatment of bulbar urethral strictures. J Urol 1999; 161(5):1501-3.

24. Mellon MJ, Bihrle R. Ventral onlay buccal mucosa urethroplasty: a 10-year experience. Int J Urol 2014; 21(2):190-3.

25. Horiguchi A, Sumitomo M, Kanbara T, et al. Oral mucosa graft urethroplasty for complicated urethral strictures. Nihon Hinyokika Gakkai Zasshi 2010; 101(3): 547-53.

26. Rosenbaum CM, Ernst L, Engel O, et al. [Redo urethroplasty with buccal mucosa] Urologe A 2017; 56(10):1274-81 [Article in German].

27. Kinnaird AS, Levine MA, Ambati D, et al. Stricture length and etiology as preoperative independent predictors of recurrence after urethroplasty: a multivariate analysis of 604 urethroplasties. Can Urol Assoc J 2014, 8(5-6):296-300. 


\title{
Проблема лечения травм уретры. Сравнение хирургических методов лечения приобретённого ятрогенного стеноза уретры и прогнозные значения неэффективности каждого из хирургических методов
}

\author{
Явуз Гюлер \\ Урологическая клиника, Частная больница „Сафа“, Стамбул, Туриия
}

Адрес для корреспонденции: Явуз Гюлер Урологическая клиника, Частная больница „Сафа“, Стамбул, Турция; E-mail: yavuzguler1976@ gmail.com; Тел.: 05058120376

Дата получения: 28 апреля 2020 Дата приемки: 30 июля $2020 \bullet$ Дата публикации: 28 февраля 2021

Образец цитирования: Güler Y. Urethral injury treatment challenge. Comparison of surgical treatments for acquired or iatrogenic urethral stenosis and predictive values for failure of each surgical method. Folia Med (Plovdiv) 2021;63(1):42-50. doi: 10.3897/ folmed.63.e53739.

\section{Резюме}

Введение: Минимально инвазивные эндоурологические вмешательства и хирургия простаты через уретру являются наиболее часто используемыми хирургическими вмешательствами в урологии в настоящее время. Одним из нежелательных осложнений, которое возникает через несколько недель после некоторых из этих операций, является стеноз уретры.

Цель: В этом исследовании наша цель состояла в том, чтобы предоставить ретроспективный обзор терапевтических методов для пациентов со стриктурой уретры после урологических вмешательств, чтобы оценить нашу успешность и данные, прогнозирующие рецидив, и определить наиболее удачный для применения метод.

Материалы и методы: С 2008 по 2017 год мы ретроспективно оценили 234, 85 и 51 пациента со стенозом уретры по ятрогенным причинам, прошедших лечение с применением соответственно прямой визуальной внутренней уретротомии (DVIU), анастомотической эксцизионной уретропластики и уретропластики с буккальным трансплантатом. Послеоперационный Qmax превышающий $15 \mathrm{~mL} / \mathrm{s}$ и цистоскоп размером > $17 \mathrm{CH}$, легко проходящий через уретру, были признаны успешными у пациентов. Групповые переменные сравнивали с использованием ANOVA. Для определения переменных с прогнозными значениями был проведен многомерный регрессионный анализ. Значимые для регрессионного анализа прогностические значения $(p<0.005)$ оценивали с помощью RОС-анализа.

Результаты: Пациенты наблюдались в среднем в течение 48 (16-56), 48 (23-60) месяцев и 50 (32-65) месяцев после DVIU, анастомоза и уретропластики соответственно, и зафиксированы успешные результаты у 75 (32.1\%), 71 (83.5\%) и 42 (82.4\%) пациентов. Многофакторный логистический регрессионный анализ показал, что возраст, СД, ИМТ и длина стеноза были независимыми прогнозными факторами успеха уретропластики, эксцизионного анастомоза и буккального трансплантата. Пороговые значения были установлены в возрасте 56.5 лет, ИМТ 30.2 кг/м² и длине стеноза 1.85 мм для пациентов с DVIU, в то время как длина стеноза 2.15 мм и 5.9 мм была определена для уретропластики, эксцизионного анастомоза и буккального трансплантата с ROC-анализом соответственно.

Заключение: DVIU в долгосрочной перспективе является неудачным методом лечения стеноза уретры. Напротив, ретропластика с резекцией / анастомозом и трансплантацией являются очень успешными методами.

\section{Ключевые слова}

анастомоз, буккальный трансплантат, стеноз, ТУР простаты, ТУР мочевого пузыря, уретра 